\title{
The Impact of E Waste Toxicity - An Emerging Global
}

\section{Challenge}

\section{Alam ZF* and Carandang JSRVI}

Biology Department, College of Science, De La Salle University, Philippines

*Corresponding author: Zeba F Alam, Biology Department, College of Science, De La

Salle University, Manila, Philippines, Tel: 0917612537; E mail:

\section{Review Article}

Volume 1 Issue 1

Received Date: August 14, 2016

Published Date: September 10, 2016

DOI: $10.23880 /$ cclsj-16000103 zeba.alam@dlsu.edu.ph

\section{Abstract}

The management of e waste has become a global challenge due to its sheer volume, and the presence of toxic and hazardous chemicals that are a threat to the environment and health. This article reviews the present status of $\mathrm{E}$ waste toxicity and its adverse impact on the environment and human health. The continuous increase in the volume of the e waste generation in the past few years and it's improper disposal, exposes the populations to the potentially hazardous substances and toxins. Most of the toxicity data has come from the populations exposed to e waste such as the informal recyclers and those living in or near e waste dumpsites. Though the genotoxic and cytotoxic effects of individual components of the e waste such as heavy metals and the organic pollutants has been established, the complex mechanisms and pathways by which the toxicity affects the cells and the DNA are still not very clear. The aim of writing this review is to bring the attention of the international scientific community to this serious issue, and to urgently focus on finding plausible solutions for efficient and sustainable management of e waste to minimize the threat to the human health and the environment.

Keywords: E-waste; Genotoxictiy; Heavy metals; E-waste dumpsites

\section{Introduction}

E-waste is one of the significant components of solid wastes in most parts of the world due to the fast turnover of the discarded electronic equipments by the consumers. There are several definitions of e waste. Electronics waste or e-waste also referred to as waste electrical and electronic equipment (WEEE), is defined as any end-oflife "equipment which is dependent on electrical current or electromagnetic field in order to work properly" [1]. According to the Basel Action Network, "e-waste encompasses a broad and growing range of electronic devices, ranging from large household devices such as refrigerators, air conditioners, cell phones, personal stereos, and consumer electronics to computers, which have been discarded by their users" [2]. Further E-waste has been classified into three main categories: Large Household appliances (Refrigerators, washing machine etc), IT or Telecom Equipments (Personal computers, Laptops, cellular phones, I pads etc) and Consumer Equipments (televisions, DVD players, Blenders, Heaters, Coffee machines etc) [Table 1]. The classification of these e-waste items is based on a range of almost 26 common components found in them. These components are used in the "building" of each item and therefore they are easily "identifiable" and "removable" [3]. These components include metal, motor/compressor, cooling, plastic, insulation, glass, rubber, wiring, concrete, transformers, 


\section{Cell \& Cellular Life Sciences Journal}

magnetron, textiles, circuit boards, fluorescent lamps, incandescent lamps, heating elements, thermostats, brominated flamed retardant (BFR)-containing plastics, batteries, external electric cables, refractory ceramic fibers, radioactive substances and electrolyte capacitors.

The rapid advancement and development in the field of technology has lead to the flooding of markets with new models year after year around the world. The introduction of the new models makes the consumers discard their old and obsolete models of their electronic gadgets especially in the fast expanding Telecommunication sector. The fast rate and the unsustainable methods of disposal of these electronic gadgets is a matter of concern for the environmentalists as these gadgets release toxic materials when stored or disposed of irresponsibly. Further, the effects of toxins can aggravate many folds due to the slow metabolic rate, and the process of bioaccumulation.

\begin{tabular}{|c|c|}
\hline \multicolumn{2}{|c|}{ E-WASTE BY THE METRIC TON } \\
\hline $\begin{array}{c}\text { Weight in } \\
\text { million tons }\end{array}$ & Type of E-waste \\
\hline 12.8 & $\begin{array}{c}\text { Small equipment (microwaves, } \\
\text { vacuums, video cameras, electric } \\
\text { razors, etc.) }\end{array}$ \\
\hline 11.8 & $\begin{array}{c}\text { Large equipment (washing machines, } \\
\text { clothes dryers, dishwashers, electric } \\
\text { stoves, photovoltaic panels, etc.) }\end{array}$ \\
\hline 7 & $\begin{array}{c}\text { Cooling and freezing equipment } \\
\text { (temperature exchangers, freezers, } \\
\text { etc.) }\end{array}$ \\
\hline 6.3 & Screens \\
\hline 3 & $\begin{array}{c}\text { Small IT (mobile phones, pocket } \\
\text { calculators, computers, printers, etc.) }\end{array}$ \\
\hline 1 & Lamps \\
\hline
\end{tabular}

Table 1: Composition of the e waste by weight*

${ }^{*}$ Credit- United Nations University (UNU) E waste report

\section{Global significance of $E$ waste}

E waste is often disposed of as a component of the solid waste collected by the municipalities around the world. In the year 2014, an estimated 41.8 Million tons of e waste was generated globally and this number is expected to reach 49.8 Million tons by the year 2018 [4] [Figure 1]. It is the vast continent of Asia, comprising of many developing countries, that has become the foremost contributor to the world with an estimated 16 Million tons of e waste generation in the year 2014 itself. Hong Kong, Singapore, Brunei were on top of the list of countries with the highest e waste generation per inhabitant with $21.5 \mathrm{~kg} / \mathrm{inh}, 19.6 \mathrm{Kg} / \mathrm{Inh}$ and $18.1 \mathrm{~kg} / \mathrm{Inh}$ respectively [4] and China, Japan and India were at the top of the list of the highest e waste generating countries $[5,6]$. Philippines known as the texting Capital of the world has a huge turnover of obsolete electronic waste however, most of the Filipinos store it in their houses and only a small fraction enters the recycling channel [7]. Due to lack of proper guidelines and regulations, the e waste in Philippines is being dumped at the Smoky Mountain, Pier 18 of Manila, Dreamland, Rosario, Cavite, and Venezuela and its impact on the environment is currently being analyzed [8]. With countries like Bangladesh, Vietnam, Thailand, struggling with the increase in the e waste generation and its improper disposal, Asia, with countries comprising of these fast growing economies is rapidly emerging as "E waste hotspot".

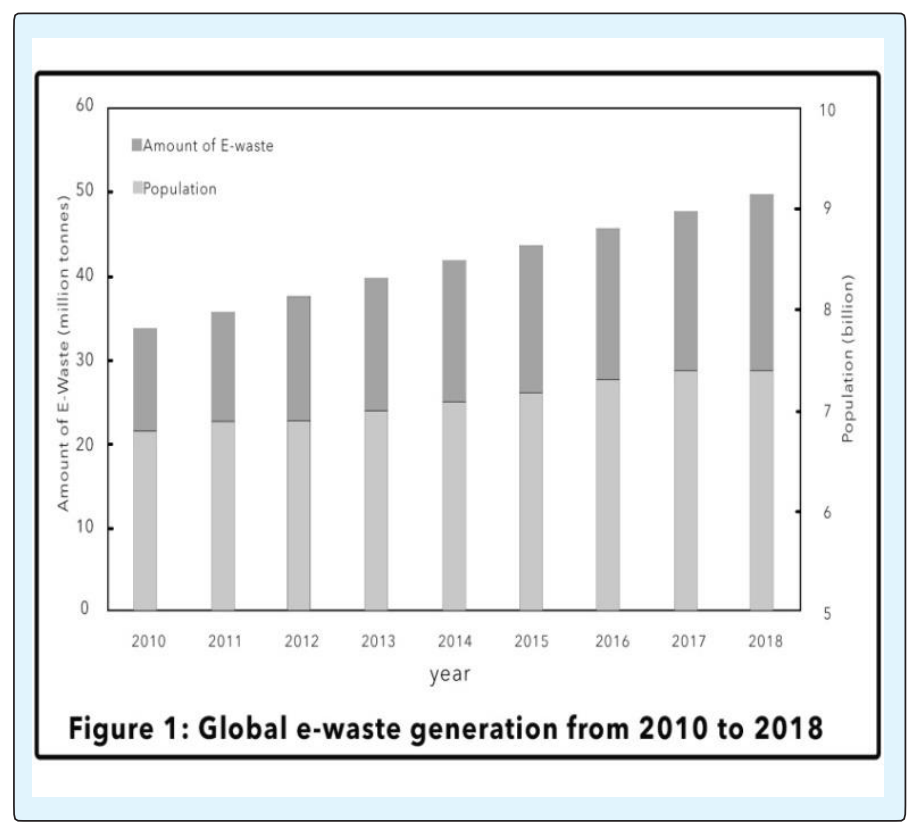

\section{Is E waste Hazardous?}

The e waste consists of 1000 different substances that can be categorized into hazardous and non-hazardous categories [9]. The e waste is composed of glass, plastics, wood, printed circuit boards, ceramics, concrete, rubber besides ferrous and non-ferrous metals [10]. The Iron and steel amount to about $50 \%$ of the e waste whereas, the non ferrous metals which constitute $13 \%$ of the e waste includes metals like copper (Cu), aluminum (Al), and precious metals like gold, silver, platinum, and palladium.

In addition, there are organic pollutants such as brominated flame retardants (polybrominated diphenyl ethers), polybrominated diphenyls, dibrominated diphenyl ethers, polychlorinated biphenyls, polychlorinated or polybrominated dioxins and dibenzofurans dioxins, found in the e waste. Often 


\section{Cell \& Cellular Life Sciences Journal}

hazardous substances such as hexavalent chromium and flame retardants and heavy metals like lead, mercury, arsenic, cadmium, selenium etc have been reported to be present more than the safe limits [11]. Among these substances, cadmium, hexavalent chromium, and beryllium have been identified as carcinogenic whereas the polybrominated diphenyl ethers, polycyclic aromatic hydrocarbons and aluminum are known genotoxins $[12,13]$. It is the presence of these substances, which pose a serious threat to the human and environment when exposed to e waste.

\section{Management of E waste}

The management and disposal of e-waste is very complicated due to the presence of toxic chemicals and heavy metals in the electronic products [14]. The presence of these hazardous materials requires utmost precautions, specialized training and cautious approach in segregation, collection, transportation, handling and treatment of the various components of $\mathrm{E}$ waste both while assembling the devices and while disposing off the $\mathrm{e}$ waste. Most of the current e waste management and disposal practices are not environmentally sound and looks unsustainable in the long run. The current practices of e waste disposal involve - using Landfills, Incineration and recycling. The Landfills are earmarked areas or land generally outside the city limits where, in addition to the e waste, the general solid waste is disposed off as well. The e waste is either dumped at these sites or buried in the trenches that are later covered with a thick layer of soil. The biggest drawback of using this method is the possibility of human populations being exposed to toxins due to the heavy metals and hazardous substances leaching out and contaminating the surrounding land and water bodies including the groundwater especially in the areas recipient of the higher annual rainfall such as Indonesia, Colombia, Philippines etc [Figure 2]. Incineration involves the burning of waste material at a temperature of $900^{\circ} \mathrm{C}$ to $1000^{\circ} \mathrm{C}$. Since the burning releases heavy fumes and large amount of residues, it is yet again a potential source of hazardous pollutants such as dioxins and furans, insulators (PCBs), fire retardants in the environment [15]. Often acids and sludge obtained from melting computer chips to recover precious metals are disposed off carelessly on the ground. This can lead to acidification of soil and contamination of water resources. The recycling practices involve the Formal sector, the informal sector and the transboundary movement of the e waste from developed countries to the third world countries. Most of the developed countries are the bulk consumers but due to stringent environmental regulations and expensive recycling cost, a substantial volume of e waste is illegally shipped to the third world countries in Asia and Africa [16]. Even most of the rich
Middle East countries do not have any proper recycling facilities hence the collected e waste is exported to Asia and Europe for recycling [17]. Recycling involves dismantling the different parts of the devices and reusing them especially the precious metals like silver, gold etc [18]. A ton of used cellular phones, for example contain about $3.5 \mathrm{~kg}$ of silver, $340 \mathrm{~g}$ of gold, $140 \mathrm{~g}$ of palladium, and $130 \mathrm{~kg}$ of copper [19]. The purpose of recycling activities in these developing countries is to recover gold, silver, copper, zinc, iron, tin, and other metals for profit $[20,21]$. However, because of a lack of stringent environmental regulation and worker protection, toxins in e-waste cause serious contaminations of local air, dust, soil, and water [21-23]. It was the plight of the Informal e waste recyclers in the e waste dumpsites of China and Ghana that brought the world's attention to the impact of e waste on human health and environment.

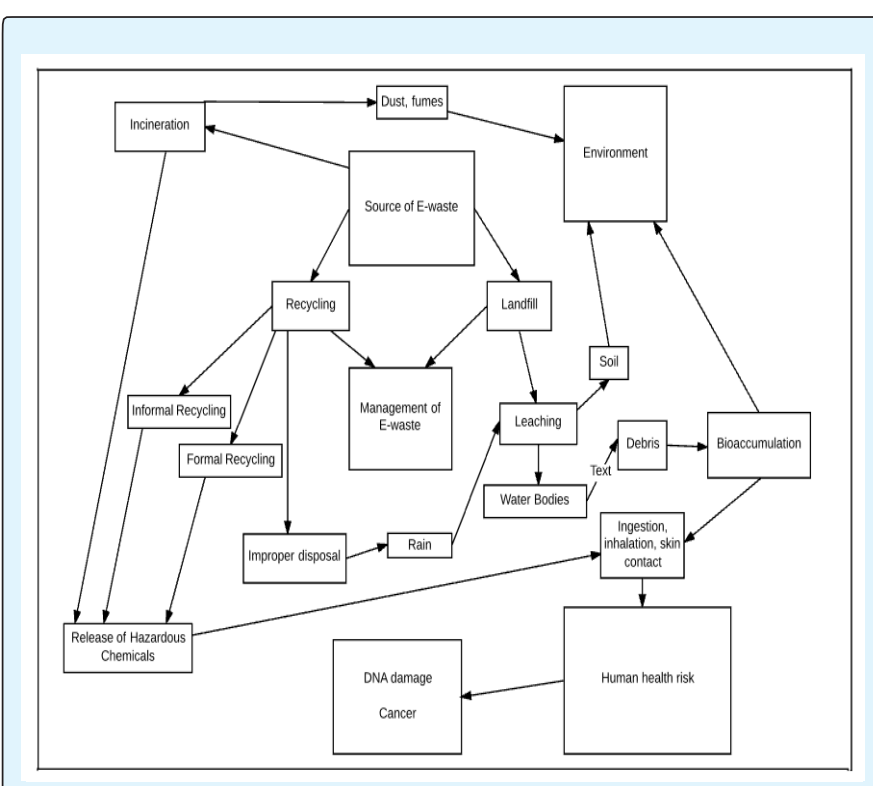

Figure 2: $\mathrm{E}$ waste in relation to human health and environment.

\section{Toxicity at $\mathrm{E}$ waste dumping sites}

Due to cheap labour and lack of regulations, $80 \%$ of the e waste generated in the developed world ends up in countries like China, India, Nigeria, Ghana, Philippines, Cambodia, Vietnam, Pakistan [24-27]. Since this E waste dumpsites are a threat to the human health and environment, proper assessment is needed to investigate their risks to human health [28].

Guiyu, China: It was a documentary film [1]Exporting Harm made by Basel Action Network on electronic waste dumping in Guiyu, China that had shocked the world with the revelation about the appalling and improper methods 


\section{Cell \& Cellular Life Sciences Journal}

of $\mathrm{E}$ waste disposal and brought to the notice the disastrous impact of e waste on the human health and environment. Guiyu in China is known as the "electronic waste dump of the world" where almost 60,000 e waste recyclers dismantle over 1.5 million pounds of e waste every year. The environmental contamination due to e waste was evident when the samples of sediments collected from two rivers in Guiyu showed acute toxicity levels due to elevated levels of heavy metals and other chemicals [29]. Since the workers recycle the components of e waste manually and without any protective covering, they are exposed to the toxins and heavy metals present in the e waste [21]. The levels of lead in the blood samples of the children living in Guiyu were found to be significantly higher than in those of children living in other cities [30]. Lower body weight, height, body mass index and lung functioning in terms of forced vital capacity were observed in children living in Guiyu [31]. In another study, higher levels of cadmium, copper and lead were deducted in the human scalp hair of residents and workers involved in high e waste recycling operations [32]. The exposure to polycyclic aromatic hydrocarbons and other organic pollutants lead to the increase in spontaneous abortions [33], stillbirths [34], and premature births [35], in the populations living in this area.

Agbogbloshie, Ghana: Agbogbloshie, in Ghana has the infamous distinction of being the biggest $\mathrm{e}$ waste dumpsite in the entire sub-Saharan region [36]. The lead, in the soil samples in and around Agbogbloshie was found to be as high as $18,125 \mathrm{ppm}$, significantly higher than US EPA standard of $400 \mathrm{ppm}$ [37]. Majority of e waste recyclers operating in this e waste dumpsite had health related complaints such as chest pains, respiratory tract infections, body pains, stomach discomfort and headaches [38]. Due to the primitive practices used for recycling the e waste, many heavy metals such as lead, cadmium, copper, zinc etc besides organic pollutants e.g. PCDD/Fs and PBDEs were detected in excess to the background levels in the sediments of local water bodies in Accra, Ghana. The exposure to these toxins and the process of bioaccumulation puts the aquatic flora and fauna in and around these water bodies at high risk [39]. The Allium cepa bioassay method used to investigate the cyto-genotoxicity of electronic waste leachates from Iloabuchi electronic market, Diobu, Rivers State illustrated significant root growth inhibition and morphological defects at all concentrations tested [40]. The same study also reported a significant increase in the induction of chromosomal aberrations as compared to the control; in the A. cepa root cells perhaps induced by the presence of high metal content in the e waste leachates present in the area. Further, higher levels of urinary polycyclic aromatic hydrocarbons (PAH) metabolite concentrations and significantly higher concentrations of some of the metals that are released during recycling activities such as $\mathrm{Fe}, \mathrm{Sb}$, and $\mathrm{Pb}$ were reported in the urine samples of the e waste recyclers as compared to the control group [41, 42].

Bengaluru, India: The demand from the vast Indian population has lead to the tremendous increase in the e waste trade in India with an estimated $500 \%$ rise in the number of old computers dumped as e waste by 2020 [43]. E waste scrap yards with the informal recyclers have come up in and around major cities like Delhi, Chennai, Mumbai, Kolkata, Bengaluru, Meerut, Ferozabad [44]. Bengaluru, also know as the Silicon Valley of India due to the presence of a thriving IT industry generates 8000 tons of e waste per year and is prominent in the danger list of cities faced with an e waste hazard [45]. The samples of soil, air dust, and human hair collected from an e-waste recycling site in Bengaluru, showed increased concentrations of trace elements such as lead, zinc, silver, cadmium, and copper compared to the reference sites [46]. Another study conducted in Delhi, the capital of India reported higher concentrations of heavy metals like As, Se, $\mathrm{Cd}, \mathrm{Cu}, \mathrm{Pb}$ and $\mathrm{Zn}$ in the surface soils and groundwater samples of e waste recycling areas and heavy accumulation of these metals in a native plant, Cynodon dactylon growing in the e waste recycling sites [47].

\section{Toxic effects of $E$ waste on humans and Environment}

The e waste toxicity has been reported to cause wide range of health problems related to the stomach, skin, respiratory tract and other organ systems besides causing genotoxicity by causing damage at the chromosomal and DNA level [48] [Table 2]. The impact of the toxic substances present in the e waste depends on the route of exposure, duration of exposure and the enhancement or the possible inhibition of the overall affect due to the interaction between the various components and interaction of these components with other other factors [49]. 


\section{Cell \& Cellular Life Sciences Journal}

Note: [1]Exporting Harm is a documentary and published report by the Basel Action Network on electronic waste dumping in Guiyu, China (Basel Action Network. 2002. Exporting Harm: The Hightech Trashing of Asia. BAN, Seattle, USA). Retrieved from: http://svtc.org/wp-content/uploads/technotrash.pdf pp. 15-22

While the personals assembling these electronic devices and the ones working in the formal and informal recycling sectors can directly get exposed to these hazardous substances, the general population can get exposed by the residual hazardous chemicals persistent in the environment due to their slow degradation. The improper disposal practices further release these toxins in to the environment.

Higher levels of polychlorinated biphenyls (PCBs) and polybrominated diphenyl ethers (PBDEs) have also been reported in the human breast milk and scalp hair samples of the primipara and multipara mothers living in two locations in the Philippines where one of the location was - Payatas, an e waste dumpsite [50]. The PBDE levels in the human milk were reported to be significantly higher in the dumpsite samples as compared to the samples from the women living in the no dump site due to inhalation of these compounds while dismantling and recycling the e waste. Similar results were reported from e waste dumpsites - Trang Minh and Bui Dau in Vietnam [51]. Further, the estimated infant intake of PBDEs from the breast milk of some e waste recycler mothers was reported to be close or higher than the reference doses recommended by USEPA [52]. Lead (Pb), one of the major toxic substance present in the e- waste has been identified to be a developmental neurotoxin with the potential of inducing neuroanatomical changes such as reduced gray matter in the prefrontal region and diffusivity changes in white matter in the young adults who were exposed to $\mathrm{Pb}$ in their childhood [53]. The studies involving measuring blood $\mathrm{Pb}$ levels in children (1-6 years old) living in the e waste recycling site, Guiyu, China indicated $50 \%$ higher value $(15 \mu \mathrm{g} / \mathrm{dL})$ than the blood $\mathrm{Pb}$ level in the control group [54]. It has been reported that blood $\mathrm{Pb}$ levels $\geq$ $10 \mu \mathrm{g} / \mathrm{dL}$ in infants is damaging to neurodevelopment and may lead to behavioral disturbance, impaired cognitive function, attention deficits and hyperactivity [55]. The elevated levels of $\mathrm{Pb}$ in the blood resulted in the lower percentages of Natural Killer cells and altered levels of platelets, IL-1 $\beta$ and IL-27 in the preschool children in Guiyu [56]. Cadmium, another heavy metal present in the e waste can affect the human health by binding to the sulfhydryl groups in proteins there by inhibiting the enzyme activity which adversely affects the physiological and biochemical reactions in the body [57]. The reduction in the absolute numbers as well as the percentage of CD4+ cells induced by the presence of lead $(>25 \mathrm{ug} / \mathrm{ml})$ in the blood of the children exposed to e waste suggests the immuno-toxicity potential of the e waste [58].

The increased frequencies of micronucleated and binucleated cells [59], and increase in chromosomal aberrations [60] and micronuclei [61] in the peripheral blood of the population exposed to e waste as compared to the control group is indicative of the genotoxicity potential of the e waste. The investigations by using the marker, 8-hydroxyguanosine $(80 \mathrm{H}-\mathrm{dG})$ to measure the oxidative DNA damage and cancer risk revealed that the Chinese e waste recyclers had more DNA damage than non-factory workers, with their DNA biomarker levels nearly as high as those observed in the cancer patients. The cellular DNA damage is known to increase the risk of cancer, therefore there is a high potential cancer risk in the e waste informal recyclers who are exposed to toxic pollutants as well as in populations living close the e waste dumpsites. A change in the expression of 182 miRNAs expression profile in the spermatozoa was reported, establishing the cause effect relationship between the exposure to e waste toxins and sperm count and quality [62]. The polluted soil and dust samples from the e waste area of Longtang, induced cell damage and DNA single strand breaks in the L02 cells through the intracellular reactive oxygen species (ROS) [63]. The proposed mechanism of action of e waste in causing the genotoxicity to the cell is by DNA fragmentation and cell death by apoptosis as observed in mouse fibroblast (NIH/3T3) cell line exposed to e waste leachates [64]. Hence, so far the studies do indicate that the e waste can cause genotoxicity as well as cytotoxicity. However, more data and investigations are needed to further substantiate this conclusion.

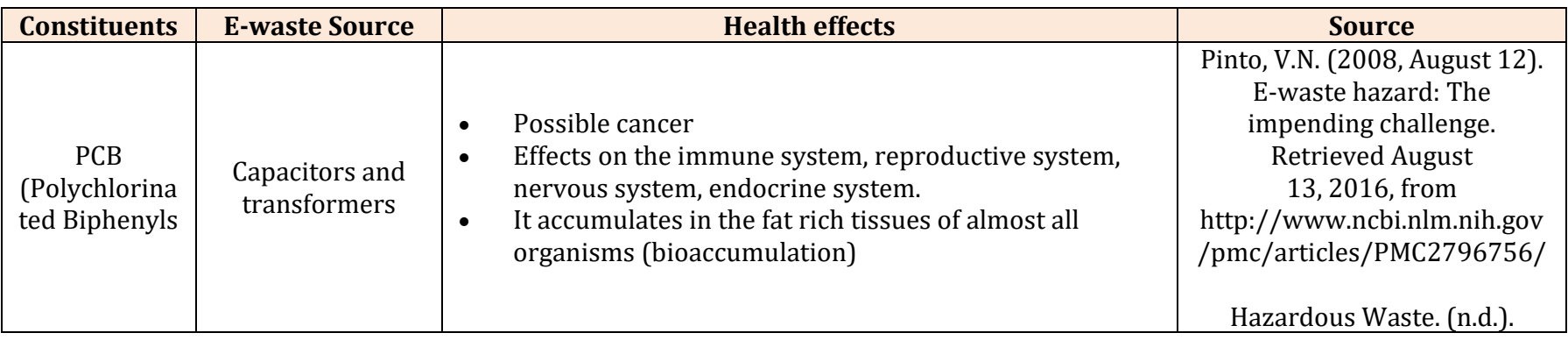




\section{Cell \& Cellular Life Sciences Journal}

\begin{tabular}{|c|c|c|c|}
\hline & & & $\begin{array}{c}\text { Retrieved August } \\
\text { 13, 2016, from } \\
\text { http://www.epa.gov/epawast } \\
\text { e/hazard/tsd/pcbs/pubs/effe } \\
\text { cts.htm }\end{array}$ \\
\hline $\begin{array}{c}\text { PVC } \\
\text { (Polyvinyl } \\
\text { chloride }\end{array}$ & $\begin{array}{l}\text { Cabling and } \\
\text { Computer } \\
\text { housing }\end{array}$ & $\begin{array}{l}\text { - Respiratory problems. } \\
\text { - } \quad \text { Affects skin, lungs and bladder. } \\
\text { (Affects reprodin and lung cancer. } \\
\text { leads to hormonal disorder) }\end{array}$ & $\begin{array}{l}\text { POLYVINYL CHLORIDE. } \\
\text { (2014, July 01). Retrieved } \\
\text { August } \\
\text { 13, 2016, from } \\
\text { http://www.cdc.gov/niosh/ip } \\
\text { csneng/neng1487.html }\end{array}$ \\
\hline $\begin{array}{l}\text { Brominated } \\
\text { Flame } \\
\text { Retardants }\end{array}$ & $\begin{array}{l}\text { Plastic housing } \\
\text { for electronic } \\
\text { equipment and } \\
\text { circuit boards }\end{array}$ & - Disrupts endocrine system functions. & $\begin{array}{l}\text { Swedish National Food } \\
\text { Administration. (2003, } \\
\text { September 29). Result } \\
\text { Filters. Retrieved August } \\
\text { 13, 2016, from } \\
\text { http://www.ncbi.nlm.nih.gov } \\
\text { /pubmed/12850100 }\end{array}$ \\
\hline Chromium & $\begin{array}{l}\text { Corrosion } \\
\text { protection of } \\
\text { untreated } \\
\text { galvanished steel } \\
\text { plates, decorators } \\
\text { and hardener }\end{array}$ & $\begin{array}{ll}\text { - } & \text { Respiratory tract irritants can cause pulmonary } \\
& \text { sensitization. } \\
\text { - } & \text { Increases the risk of lungs, nasal, and sinus cancer. } \\
\text { - } & \text { Severe dermatitis and usually painless skin ulcers. } \\
\text { - } & \text { Increased risk of respiratory system cancers. } \\
\text { - Indicated that reversible renal tubular damage can } \\
\text { occur. } \\
\text { - Severe liber abnormalities. } \\
\text { - Caustic and irritating to gastrointestinal mucosal } \\
\text { tissue. } \\
\text { - Cardiovascular collapse. } \\
\text { - Hematological toxicity. } \\
\text { DNA damage, gene mutation, sister chromatid } \\
\text { exchange, chromosomal aberrations in a number of } \\
\text { targets, including animal cells, in vivo and animal and } \\
\text { human cells in vitro. }\end{array}$ & $\begin{array}{l}\text { Health effects of Hexavalent } \\
\text { Chromium. (2001 July). } \\
\text { Retrieved August } \\
\text { 14, 2016, from } \\
\text { www.osha.gov/OshDoc/data_ } \\
\text { General_Facts/hexavalent } \\
\text { _chromium.pdf } \\
\\
\text { Chromium (Cr) Toxicity: Key } \\
\text { Concepts. (2008, December } \\
\text { 8). Retrieved August } \\
\text { 13, 2016, from } \\
\text { http://www.atsdr.cdc.gov/cse } \\
\text { m/csem.asp?csem=10 }\end{array}$ \\
\hline Cadmium & $\begin{array}{l}\text { Chip resistors and } \\
\text { semiconductors }\end{array}$ & $\begin{array}{l}\text { Acute inhalation exposure (high levels in short period } \\
\text { of time) can result in flulike symptoms (chills, fever } \\
\text { and muscle pain) and can damage the lungs. } \\
\text { - Chronic exposure (low level over an extended period of } \\
\text { time) can result in kidney, bone and lung disease. } \\
\text { Causes neural damage. }\end{array}$ & $\begin{array}{c}\text { Public Health Statement for } \\
\text { Cadmium. (2015, January 21). } \\
\text { Retrieved August } \\
\text { 13, 2016, from } \\
\text { http://www.atsdr.cdc.gov/ph } \\
\text { s/phs.asp?id=46\&tid=15 } \\
\\
\text { Safety and Health Topics: } \\
\text { Cadmium. (n.d.). Retrieved } \\
\text { August } \\
\text { 13, 2016, from } \\
\text { http://www.oshagov/SLTC/C } \\
\text { admium/healtheffects.html } \\
\end{array}$ \\
\hline Lead & $\begin{array}{l}\text { Solder in PCBs, } \\
\text { glass panels, and } \\
\text { gaskets in } \\
\text { computer } \\
\text { monitors }\end{array}$ & $\begin{array}{l}\text { - } \quad \text { Lead poisoning. } \\
\text { - } \\
\text { - } \quad \text { Neurialogiogical effects and mental retardation. } \\
\text { Heduced fertility. } \\
\text { - } \\
\text { Affects brain development in children. }\end{array}$ & $\begin{array}{c}\text { Safety and Health Topics: } \\
\text { Lead. (n.d.). Retrieved August } \\
\text { 13, 2016, from } \\
\text { http://www.osha.gov/SLTC/l } \\
\text { ead/healtheffects.html } \\
\\
\text { LEAD. (2013, September 30). } \\
\text { Retrieved August } \\
\text { 13, 2016, from } \\
\text { http://www.cdc.gov/niosh/to } \\
\text { pics/lead/health.html }\end{array}$ \\
\hline
\end{tabular}




\section{Cell \& Cellular Life Sciences Journal}

\begin{tabular}{|c|c|c|c|}
\hline Mercury & $\begin{array}{c}\text { Relays and } \\
\text { switches, PCBs }\end{array}$ & $\begin{array}{l}\text { Harmful effects on the nervous, immune and digestive } \\
\text { system, lungs and kidneys, and may be fatal. } \\
\text { - } \quad \text { Corrosive to the skin, eyes and gastro intestinal tract, } \\
\text { and may induce kidney toxicity. } \\
\text { - } \quad \text { Neurological and behavioural disorders. } \\
\text { Mild, subclinical signs of central nervous system } \\
\text { toxicity. } \\
\text { Kidneys effects have been reported, ranging from } \\
\text { increased protein in the urine to kidney failure. }\end{array}$ & $\begin{array}{l}\text { Mercury and health. (2016, } \\
\text { January). Retrieved August } \\
\text { 13, 2016, from } \\
\text { http://www.who.int/mediace } \\
\text { ntre/factsheets./fs361/en/ }\end{array}$ \\
\hline Nickel & $\begin{array}{l}\text { Rechargable } \\
\text { batteries and } \\
\text { electron gun }\end{array}$ & $\begin{array}{l}\text { - } \\
\text { - Stlergic reaction (skin rash and etc.). } \\
\text { blood (increased red blood cells) and kidneys } \\
\text { (increased protein in the urine). } \\
\text { - Chronic bronchitis, reduced lung function and cancer of } \\
\text { the lung and nasal sinus. }\end{array}$ & $\begin{array}{l}\text { Public Health Statement for } \\
\text { Nickel. (2015, January 21). } \\
\text { Retrieved August } \\
\text { 13, 2016, from } \\
\text { http://www.atsdr.cdc.gov/PH } \\
\text { S/PHS.asp?id=243\&tid=44 }\end{array}$ \\
\hline
\end{tabular}

Table 2: Impact of some of the components of E waste on Human Health.

\section{Results and Discussion}

Till date, most of the data and the information about the impact of e waste have come from samples taken from the e waste dumpsites in China and Nigeria. However, to study the full impact of the composite nature of the e waste, which includes heavy metals, organic pollutants and other compounds, the laboratory-based experiments should be designed to establish the dose response relations between these complex chemical mixtures and their impact on different in vitro and in vivo assay systems. New models, efficient and sensitive assay systems, a standardized questionnaire that can be validated by the available definitions of e waste will help to generate legitimate scientific evidence to further understand the e waste toxicity. Further, the extent of damage due to the combined action of chemicals present in the e waste with factors such as life style which includes smoking, drinking alcohol, nutritional status, gender specific difference in the response, needs further investigation to fully understand and establish the range of effects caused by exposure to e waste. Since the e waste is composed of many hazardous chemicals, the "cocktail effect' where the individual components in a mixture do not each separately cause harmful effects but the mixture itself can produce harmful effects [65], needs further

research to resolve the extent to which each of these hazardous chemicals cause genotoxicity and cytotoxicity.

The fact is that in many countries the $\mathrm{E}$ waste is still considered and disposed off as part of the solid waste, poses another limitation in investigating the effects of the E waste as a separate entity. However, more data and scientific evidence is needed to understand the full potential of e waste toxicity. To manage the e waste and protect the environment and human populations from the toxicity of the e waste, an interdisciplinary approach with collaboration between the scientific community, experts, policy makers, manufactures and recyclers in all the countries is the need of the hour.

\section{Conclusion}

E waste is purely a manmade menace, which has now become a global issue and needs immediate attention with multi pronged approach to find tangible solutions to deal with the problem. The improper disposal of e waste can cause lot of harm and damage to the environment as well as to the health of the people due to the presence of hazardous substances. Hence, extensive research by the scientific community with an interdisciplinary approach is needed to investigate and assess the overall and full potential of the toxicity of the e waste. The collaboration between the various stakeholders such as manufacturers, recyclers and consumers should be encouraged to reduce the overall e waste generation, adopt safe recycling practices thereby minimize the exposure to the toxicity of the e waste and save the environment and human population.

\section{Acknowledgement}

The authors would like to acknowledge the contribution of Miss Isabella Bondoc, an undergraduate student at De La Salle University, in the preparation of this manuscript.

\section{References}




\section{Cell \& Cellular Life Sciences Journal}

1. United Nations Environment Programme (UNEP) (2007) E-waste volume I: inventory assessment manual. Osaka, Japan: United Nations Environmental Programme, Division of Technology, Industry and Economics, International Environmental Technology Centre.

2. Puckett J, Byster L, Westervelt S, Gutierrez R, Davis S, et al. (2002) Exporting harm: the high-tech trashing of Asia. The Basel Action Network and Silicon Valley Toxics Coalition.

3. Pinto VN (2008) E waste hazard: The impending challenge. Indian J Ocuup Environ Med 12(2): 65-70.

4. Baldé CP, Wang F, Kuehr R, Huisman J (2015) The global e-waste monitor-2014, United Nations University, IAS - SCYCLE, Bonn, Germany.

5. Hotta Y, Elder M, Mori H, Tanaka M (2008) Policy considerations for establishing an Environmentally sound regional material flow in East Asia. Journal of Environment and Development 17(1): 26-50.

6. Hotta Y, Kojima S (2012) Policy Framework for International Collaboration towards Sustainable Resource Circulation and Management in Asia, in IGES (ed.), IGES White Paper IV 2012 Greening Governance in Asia-Pacific, Hayama: IGES,Japan, pp 157-186.

7. Alam Z (2016) The Assessment of the of E-Waste Management Generated from Cellular Phones, Laptops, and Personal Computers in the Philippines. Manila Journal of Science 9(2016): 27-42.

8. Gutierrez R, Agarrado G (2011) The vanishing ewastes of the Philippines.

9. Lundgren K (2012) The global impact of e-waste: Addressing the challenge.

10. Puckett J, Byster L, Westervelt S, Richard Gutierrez, Sheila Davis, et al. (2002) Exporting Harm. The hightech trashing of Asia. The basel action network (BAN) and Silicon Valley Toxics Coalition (SVTC).

11. Widmer R, Oswald-Krapf H, Sinha-Khetriwal D, Schnellmann M, Böni H (2005) Global perspectives on e-waste. Environmental Impact Assessment Review 25(5): 436-458.

12. World Health Organization International Agency for Research on Cancer (IARC) (2012) A review of human carcinogens: chemical agents and related occupations. IARC Monographs on the Evaluation of Carcinogenic Risks to Humans 100: 249-378.

13. Hirano M, Tanaka S, Asami O (2013) Classification of polycyclic aromatic hydrocarbons based on mutagenicity in lung tissue through DNA microarray. Environ Toxicol 28(11): 652-659

14. Ramesh Babu B, Parande AK, Basha CA (2007) Electrical and electronic waste: a global environmental problem. Waste Management and Research 25(4): 307-318.

15. Li H, Yu L, Sheng G, Fu J, Peng P (2007) Severe PCDD/F and PBDD/F pollution in air around an electronic waste dismantling area in China. Environ Sci Technol 41(16): 5641-5646.

16. Levinson T, Folman C, Lietzmann J (2008) E-waste legislation in the European Union and the Basel Convention, In: JOHRI R (eds) E-waste: implications, regulations, and management in India and current global best practices. New Delhi, India: The Energy and Resource Institute.

17. Alameer $H$ (2014) Assessment and evaluation of waste electric and electronics disposal system in the middle-east. European Scientific Journal edition 10(12): 1857-7881.

18. E-waste Generation Scenario, Website: http://envis.maharashtra.gov.in/ envis data/files/ Ewastgeneration_scenario.html

19. Balde CP, Kuehr R, Blumenthal K, Fondeur Gill S, Kern $M$, et al. (2015) E-waste statistics: Guidelines on classifications, reporting and indicators. The United Nations University, IAS - SCYCLE, Bonn, Germany. 2015.

20. Huo X, Peng L, Xu X, Zheng L, Qiu B, et al. (2007) Elevated Blood Lead Levels of Children in Guiyu, an Electronic Waste Recycling Town in China. Environ Health Perspect 115(7): 1113-1117.

21. Wong MH, Wu SC, Deng WJ, Yu XZ, Luo Q (2007) Export of Toxic Chemicals-a Review of the Case of Uncontrolled Electronic-Waste Recycling. Environ Pollut 149(2): 131-140.

22. Ogunseitan OA, Schoenung JM, Saphores JD, Shapiro AA (2009) Science and regulation, The electronics 


\section{Cell \& Cellular Life Sciences Journal}

revolution: from e-wonderland to ewasteland. Science 326 (5953): 670-671.

23. Schmidt CW (2006) Unfair trade: e-waste in Africa. Environ Health Perspect 114: a232-a235.

24. Ni HG, Zeng EY (2009) Law enforcement and global collaboration are the keys to containing e-waste tsunami in China. Environ Sci Technol 43(11): 39913994.

25. Ramesh BB, Parande AK, Ahmed Basha C (2007) Electrical and electronic waste: a global environmental problem, Waste Manag Res 25(4): 307-318.

26. Kojima M (2005) Chapter 6: Transboundary movements of recyclable resources in Southeast Asia (Institute of Developing Economies).

27. Ray A (2008) Waste management in developing Asia: Can trade and cooperation help? in The Journal of Environment \& Development 17(1): 3-25.

28. Yáñez L, Ortiz D, Calderón J, Batres L, Carrizales L, et al. (2002) Overview of human health and chemical mixtures: problems facing developing countries. Environ Health Perspect 110 (6): 901-909.

29. Wang F, Leung AO, Wu SC, Yang MS, Wong MH (2009) Chemical and eco-toxicological analyses of sediments and elutriates of contaminated rivers due to e-waste recycling activities using a diverse battery of bioassays. Environ Pollut 157 (7): 2082-2090.

30. Huo X, Peng L, Xu X, Zheng L, Qiu B, et al. (2007) Elevated Blood Lead Levels of Children in Guiyu, an Electronic Waste Recycling Town in China, Environmental Health Perspectives 115(7): 11131117.

31. Zheng G, Xu X, Li B, Wu K, Yekeen TA, et al. (2013) Association between lung function in school children and exposure to three transition metals from an ewaste recycling area. J Expo Sci Environ Epidemiol 23(1): 67-72.

32. Wang T, Fu J, Wang Y, Liao C, Tao Y, et al. (2009) Use of scalp hair as indicator of human exposure to heavy metals in an electronic waste recycling area. Environ Pollut 157(8-9): 2445-2451.

33. Wu K, Xu X, Peng, Liua J, Guo Y, et al. (2012) Association between maternal exposure to perfluorooctanoic acid (PFOA) from electronic waste recycling and neonatal health outcomes. Environ Int 48: 1-8.

34. Guo Y, Huo X, Wu K, Liu J, Zhang Y, et al. (2012) Carcinogenic polycyclic aromatic hydrocarbons in umbilical cord blood of human neonates from Guiyu, China. Sci Total Environ 427-428: 35-40.

35. Xu X, Yang H, Chen A, Zhou Y, Wu K, et al. (2012) Birth outcomes related to informal e-waste recycling in Guiyu, China. Reprod. Toxicol. 33(1): 94-98.

36. (2012) Agbogloshie, West Africa's biggest e-waste dump. Crikey Company.

37. Caravanos J, Clark E, Fuller R, Lambertson C (2011) Assessing Worker and Environmental Chemical Exposure Risks at an e-Waste Recycling and Disposal Site in Accra, Ghana. Journal of Health and Pollution 1(1): 16-25.

38. Asampong E, Dwuma-Badu K, Stephens J, Srigboh R, Neitzel R, et al. (2015) Health seeking behaviours among electronic waste workers in Ghana. BMC Public Health 15: 1065.

39. Huang J, Nkrumah PN, Anim DO, Mensah E (2014) Ewaste disposal effects on the aquatic environment: Accra, Ghana. Rev Environ Contam Toxicol 229: 1934.

40. Babatunde B, Anabuike F (2015) In Vivo Cytogenotoxicity of Electronic Waste Leachate from Iloabuchi Electronic Market, Diobu, Rivers State, Nigeria on Allium Cepa. Challenges 6(1): 173-187.

41. Asante KA, Agusa T, Biney CA, Agyekum WA, Bello M, et al. (2012) Multi-trace element levels and arsenic speciation in urine of e-waste recycling workers from Agbogbloshie, Accra in Ghana. Sci Total Environ 424: 63-73.

42. Feldt T, Fobil JN, Wittsiepe J, Wilhelm M, Till H, et al. (2013) High levels of PAH-metabolites in urine of ewaste recycling workers from Agbogbloshie, Ghana. Sci Total Environ 466-467: 369-376.

43. Schluep M, Hageluken C, Kuehr R, Magalini F, Maurer C, et al. (2009) Recycling: From e-waste to resources, Sustainable Innovation and Technology Transfer Industrial Sector Studies (Nairobi and Bonn, UNEP and STeP). 
44. Sinha S, Mahesh P Donders E, Van Breusegem W (2011) Waste electrical and electronic equipment: The EU and India: Sharing best practices.

45. Jha MK, Kumar A, Kumar V, Jae-chun Lee (2011) Prospective Scenario of E-Waste Recycling in India. Recycling of electronic waste II, proceedings of the second symposium, TMS the minerals, metals and materials society.

46. Ha NN, Agusa T, Ramu K, Tanabe S, Murata S, et al. (2009) Contamination by trace elements at e-waste recycling sites in Bangalore, India. Chemosphere 76(1): 9-15.

47. Pradhan JK, Kumar S (2014) Informal e-waste recycling: environmental risk assessment of heavy metal contamination in Mandoli industrial area, Delhi, India. Environ Sci Pollut Res Int 21(13): 7913-7928.

48. Nordbrand S (2009) Out of control: E-waste trade flows from the EU to developing countries. SwedWatch.

49. Grant K, Goldizen FC, Sly PD, Brune MN, Neira M, et al. (2013) Health consequences of exposure to e-waste: a systematic review, The Lancet Global Health 1(6): e350-361.

50. Malarvannan G, Isobe T, Covaci A, Prudente M, Tanabe S (2013) Accumulation of brominated flame retardants and polychlorinated biphenyls in human breast milk and scalp hair from the Philippines: levels, distribution and profiles. Sci Total Environ 442: 366-379.

51. Tue NM, Sudaryanto A, Minh TB, Isobe T, Takahashi S, et al. (2010) Center for Marine Environmental Studies (CMES), Ehime Universit Accumulation of polychlorinated biphenyls and brominated flame retardants in breast milk from women living in Vietnamese e-waste recycling sites. Sci Total Environ 408(9): 2155-2162.

52. Electronics Waste Management in the United States approach 1 final (2008) Washington, DC, USA: Office of Solid Waste US Environmental Protection Agency.

53. Brubaker CJ, Schmithorst VJ, Haynes EN, Dietrich KN, Egelhoff JC, et al. (2009) Altered myelination and axonal integrity in adults with childhood lead exposure: a diffusion tensor imaging study. Neurotoxicology 30(6): 867-875.
54. Zheng L, Wu K, Li Y, Qi Z, Han D, et al. (2008) Blood lead and cadmium levels and relevant factors among children from an e-waste recycling town in China. Environ Res 108(1): 15-20.

55. Bellinger DC (2004) Lead. Pediatrics 113(4): 10161022.

56. Zhang Y, Huo X, Cao J, Yang T, Xu L, et al. (2016) Elevated lead levels and adverse effects on natural killer cells in children from an electronic waste recycling area. Environ Pollut 213: 143-150.

57. Koedrith P, Kim H, Weon JI, Seo YR (2013) Toxicogenomic approaches for understanding molecular mechanisms of heavy metal mutagenicity and carcinogenicity. Int J Hyg Environ Health 216(5): 587-598.

58. Li S, Zhengyan Z, Rong L, Hanyun C (2005) Decrease of $\mathrm{CD}+\mathrm{T}$-lymphocytes in children exposed to environmental lead. Biol Trace Elem Res 105(1-3): 19-25.

59. Wang Q, He AM, Gao B, Chen L, Yu QZ, et al. (2011) Increased levels of lead in the blood and frequencies of lymphocytic micronucleated binucleated cells among workers from an electronic-waste recycling site. J Environ Sci Health A Tox Hazard Subst Environ Eng 46(6): 669-676.

60. Liu Q, Cao J, Li KQ, Miao XH, Li G, et al. (2009) Chromosomal aberrations and DNA damage in human populations exposed to the processing of electronics waste. Environ Sci Pollut Res Int 16(3): 329-338.

61. Chen L, Guo H, Yuan J, He M, Chen D, et al. (2010) Polymorphisms of GSTT1 and GSTM1 and increased micronucleus frequencies in peripheral blood lymphocytes in residents at an e-waste dismantling site in China. J Environ Sci Health A Tox Hazard Subst Environ Eng 45(4): 490-497.

62. Li Y, Li M, Liu Y, Song G, Liu N (2012) A microarray for microRNA profiling in spermatozoa from adult men living in an environmentally polluted site. Bull Environ Contam Toxicol 89: 1111-1114.

63. Wang L, Hou M, An J, Zhong Y, Wang X, et al. (2011) The cytotoxic and genetoxic effects of dust and soil samples from E-waste recycling area on L02 cells. Toxicol Ind Health 27(9): 831-839. 


\section{Cell \& Cellular Life Sciences Journal}

64. Alabi OA, Bakare AA (2011) Genotoxicity and mutagenicity of electronic waste leachates using animal bioassays. Toxicological \& Environmental

65. Kemi (Swedish Chemicals Agency) Combination effects of chemicals.
(2011) 